\title{
THE APRIL MEETING IN ATLANTIC CITY
}

The five hundred ninetieth meeting of the American Mathematical Society was held at the Chalfonte-Haddon Hall Hotels in Atlantic City on April 16-19, 1962. There were 573 persons registered, of whom 302 were members of the Society.

There was a Symposium in five sessions on the Interactions between Mathematical Research and High Speed Computing, jointly sponsored by the Association for Computing Machinery and the American Mathematical Society, with the financial support of the U. S. Army Research Center, Durham and the National Science Foundation. The proceedings of this symposium, together with those of a Symposium on Experimental Arithmetic at the April Meeting in Chicago, will be published through an Editorial Committee consisting of Professors John Todd, N. C. Metropolis, C. B. Tompkins and A. H. Taub.

By invitation of the Committee to Select Hour Speakers for Eastern Sectional Meetings, Professor Joseph B. Keller of New York University addressed the Society on April 18 on Some problems in wave propagation.

By invitation of the same committee, Professor David B. Lowdenslager of Princeton University spoke on April 19 on The theorems of $F$. and $M$. Riesz on functions analytic in the unit circle.

There were six sessions for contributed papers on the afternoon of April 18 and on April 19, at which 44 papers were presented. The chairmen of the sessions were Professors W. F. Eberlein, P. C. Hammer, H. M. MacNeille, Selby Robinson, J. A. Schatz and J. D. Swift.

The Council met on Wednesday, April 18, 1962 at 5:00 P.M.

The Secretary announced the election of the following nineteen persons to ordinary membership in the Society:

Mr. David N. Barros, Chance-Vought Aircraft, Grand Prairie, Texas;

Dr. Robert K. Brayton, International Business Machines Corp., Yorktown Heights, New York;

Mr. Klaus E. Eldridge, Oklahoma State University, Stillwater, Oklahoma;

Mr. Karen N. Frederick, New York University, New York, New York;

Mr. Seymour L. Friedman, General Precision Inc., Glendale, California;

Mr. Martin M. Guterman, Cornell University, Ithaca, New York;

Dr. Hubert M. Hill, Tennessee Eastman Company, Kingsport, Tennessee;

Mr. Joseph R. Johler, National Bureau of Standards, Boulder, Colorado;

Mr. Roy A. Lippmann, University of Arizona, Tucson, Arizona;

Mr. Donald W. Marshall, General Foods Limited, La Salle, Quebec, Canada;

Mr. John J. H. Miller, Massachusetts Institute of Technology, Cambridge, Massachusetts; 
Mr. James T. Murphy, Jr., The Martin Company, Orlando, Florida; Dr. J. I. Nassar, Lehigh University, Bethlehem, Pennsylvania; Mr. Wesley G. Nilson, Ebasco Services Inc., New York, New York; Mrs. Mary V. Powell, The Trane Company, La Crosse, Wisconsin; Mr. Otto G. Ruehr, University of Michigan, Ann Arbor, Michigan; Mr. Vanamamalai Seshadri, Southern Methodist University, Dallas, Texas; Mr. Leonard S. Silver, Brandeis University, Waltham, Massachusetts; Mr. William L. Stetzenmeyer, Burroughs Corporation, Pasadena, California;

The Secretary announced that the following had been admitted to the Society in accordance with reciprocity agreements with various mathematical organizations:

Union Matematica Argentina: Mr. Enrique Vidal-Abascal;

The London Mathematical Society: Dr. Felix M. Arscott, Mr. John N. Whiteley; Deutsche Mathematiker Vereinigung: Mr. Peter Werner;

Calcutta Mathematical Society: Mr. Amiya C. Banerji, Mr. Diswa N. Mitra, Mr. Samarendra K. Mitra, Mr. Ananta M. Sen Gupta;

Edinburgh Mathematical Society: Dr. Daniel Martin.

The Secretary reported that Professor Gail Young represented the Society at the Inauguration of J. A. Hunter as President of Louisiana State University; that Professors Saunders MacLane and C. B. Morrey had accepted invitations to deliver the Colloquium Lectures in 1963 and 1964 respectively; that Professor Claude Shannon had accepted the invitation to deliver the 1963 Gibbs Lecture.

The Council voted to set a meeting at Dartmouth College on October 27, 1962.

It was reported that the following were elected to Institutional Membership in the Society: The Bronx Community College, Bronx, New York; Howard Payne College, Brownwood, Texas; Hobart and William Smith College, Geneva, New York; The National Biomedical Research Foundation, New York.

It was reported that Standard Oil Company of New Jersey and Socony Mobile Oil Company, Incorporated, were elected to Corporate Membership.

It was reported that meetings were set at Northwestern University on November 23 and 24, 1962, and at New Mexico State University, University Park, New Mexico, on April 26 and 27, 1963.

It was reported that the Executive Committee had approved the report of the Applied Mathematics Committee, and authorized the holding of a Symposium on Stochastic Processes in Mathematical Physics and Engineering in the Spring of 1963 and a Summer Seminar in 1963 on Space Mathematics. The Invitations and Organizing Committee recommended for the former consists of Richard Bellman (Chairman), A. Barucha-Reid, M. Kac, J. M. Richardson, J. Keller, 
Lofti Zadah, and David Slepian. J. Barkeley Rosser was recommended as Chairman of the Organizing Committee for the latter; the remainder of the Committee is yet to be recruited.

The Council voted to approve the recommendation of the Committee on Translations and the Executive Committee that the journal TRUDY MOSKOVSKOGO MATEMATICSKOGO OBSCESTVA be translated in its entirety. It also expressed the opinion that the question of having or not having associate editors of the Transactions or Proceedings should be left to the respective Editorial Committees.

The Secretary reported that Dr. S. H. Gould was resigning as Executive Editor of Mathematical Reviews effective June 1, 1962, and a Committee consisting of the Editorial Board of the Reviews, augmented by J. L. Doob, W. Feller, R. P. Boas, and the Secretary had been appointed to seek a new Executive Editor. The Council authorized the Executive Committee to recommend to the Trustees the next Executive Editor of the Reviews.

JoHN W. GREen

Secretary

Everetr Pitcher

Associate Secretary 